\title{
Addressing Social Exclusion: Analyses from South Asia and Southern Africa
}

In recent years, the health inequities that exist within and between countries have been receiving increasing levels of attention. Socially-determined health disparities, such as the differences in the maternal mortality ratios in Kuwait (4 per 100,000 livebirths), Sri Lanka (58 per 100,000 livebirths), Bangladesh (570 per 100,000 livebirths), and Afghanistan (1,800 per 100,000 livebirths) are increasingly recognized as unfair and avoidable (1). Despite amplified attention on national and global policy agenda, few countries have been able to systematically reduce socially-determined inequities in health (2).

In 2005, the World Health Organization established the Commission on Social Determinants of Health to provide evidence-based advice on how to promote health equity. The Social Exclusion Knowledge Network (SEKN) was established as one of nine knowledge networks supporting this Commission. During a multi-year international assessment, members of the SEKN based in Europe, southern Africa, South America, and South-East Asia surveyed policies and actions that address disadvantage and marginalization. The SEKN found that many policies and actions focus on the groups who are defined as being disadvantaged, marginalized, or excluded from mainstream society but very few policies or actions focus on changing the processes that cause or perpetuate the disadvantage, marginalization, or exclusion.

The SEKN acknowledged and explored relationships among the economic, social, political and cultural processes which exclude access and participation in society and thereby affect health and well-being. The SEKN developed and promoted a framework for policy and programme development and analysis, which focuses on the exclusionary processes that cause problems rather than on particular groups being 'excluded'. This approach directs attention

Correspondence and reprint requests should be addressed to:

Dr. Heidi Bart Johnston

Public Health Sciences Division

ICDDR,B

GPO Box 128, Dhaka 1000

Bangladesh

Email: heidibartjohnston@gmail.com towards the root causes of social exclusion as opposed to a more limited focus on the differential outcomes of certain groups and thus has practical value for policy and programme design and analysis (3).

This special social exclusion issue of the Journal of Health, Population and Nutrition (JHPN) presents original research describing exclusion and its relationships with health and policy analyses that describe policies and actions that were developed or have the potential to address exclusion. Many papers in this issue of the Journal were initially developed as background papers for the South-East Asia hub of the SEKN. The original research articles included in this issue of the Journal make important contributions in the face of the overwhelming need for additional evidence on relationships between social exclusion and health. The collection of papers in its entirety demonstrates the importance of multisectoral approaches to addressing social exclusion: while public-sector commitment is essential, so too is commitment from civil society; non-governmental organizations, and private sectors can also make significant contributions to reducing social exclusion.

In the overview paper titled "Relationships of exclusion and cohesion with health: the case of Bangladesh", I provide background to social exclusion theory and discuss modifications for the application of social exclusion theory to developingcountry settings (4). In the paper titled "Living on the extreme margin: social exclusion of the transgender population (hijra) in Bangladesh", Khan et al. present a rich description of social exclusion of the hijra population in Bangladesh, arguing that, before prevention of HIV-transmission interventions can be effective broadly in this population, the underlying factors that drive the hijra to highrisk behaviours must be addressed (5). Koehlmoos et al. quantify the risk factors of the homeless in Dhaka, Bangladesh and identify that, because of their geographical stability, this group can participate in programmes to increase their access to resources of society (6). Modie-Moroka examines relationships among neighbourhood characteristics, social capital, and health outcomes in Francistown, Botswana (7). Naved et al. review results of 
an initiative to provide psychological counselling in rural Bangladesh. In this case, the counselling was for abused women (8).

The original policy and programme analyses in this issue of the Journal describe policies and actions that have the potential to address exclusion. These policies and actions can be categorized into policies and actions by the state, non-governmental organizations (NGOs), civil society, and the private sector. Rispel et al. review and assess three categories of social inclusion policies-cash-transfers, free social services, and specific institutional arrangements for programme integration-as implemented by public sectors in five southern African countries (9). Schurmann reviews the state-implemented Bangladesh Female Secondary School Stipend Project-a conditional cash-transfer programmedesigned to motivate families to send daughters to secondary school (10). Schurmann and Johnston assess NGO-run microcredit programmes as a tool for social closure (11). Ahmed reviews evidence on the impact of the Targeting the Ultrapoor Programme-an NGO-implemented programme for people too poor to benefit from microcredit-on social exclusion and health equity (12). Schurmann and Mahmud consider the very different incarnations of civil society and describe several examples of civil society action for the promotion of health equity in Bangladesh (13).

Werner looks at several examples of private-sector action to reduce social exclusion and promote health equity, first reviewing micro-insurance programmes in Bangladesh and contrasting these to programmes in India (14). Werner also describes strategic corporate social responsibility as implemented in Bangladesh, where some private-sector companies are working to positively impact social status, earning potential, and access to services and resources for socially-excluded populations (15).

In the paper titled "Strategies to reduce exclusion among populations living in urban slum settlements in Bangladesh", Rashid considers how initiatives from NGOs, the public sector, and civil society can address exclusion and health among urban slum populations (16). In the paper titled "HIV/AIDS interventions in Bangladesh: what can application of a social exclusion framework tell us?", Khosla explores how HIV programmes in Bangladesh may have limited their impact by not taking into account the underlying exclusionary factors that contribute to high-risk behaviour for HIV transmission (17).
This inaugural special issue of the Gender Health and Human Rights section of JHPN focusing on social exclusion demonstrates the Journal's commitment to addressing the social determinants of health. The placement of this collection of papers on social exclusion and health in one special issue aims to encourage increased attention on the various policies and actions to address social exclusion and health that can be developed, implemented, and assessed, with the goal of altering the sources of exclusion to promote social justice and health equity.

\section{REFERENCES}

1. World Health Organization. Maternal mortality in 2005: estimates developed by WHO, UNICEF, UNFPA, and the World Bank. Geneva: World Health Organization, 2007. 40 p. (http://whqlibdoc.who. int/publications/2007/9789241596213_eng.pdf, accessed on 24 April 2009).

2. World Health Organization. Closing the gap in a generation: health equity through action on the social determinants of health. Geneva: World Health Organization 2008. 256 p. (http://whqlibdoc.who. int/publications/2008/ 9789241563703_eng.pdf, accessed on 24 April 2009).

3. Popay J, Escorel S, Hernández M, Johnston H, Mathieson J, Rispel L. Understanding and tackling social exclusion: final report to the WHO Commission on Social Determinants of Health from the Social Exclusion Knowledge Network. Geneva: World Health Organization, 2008. 207 p. (http://www.who.int/ social_determinants/knowledge_networks/final_reports/sekn_final\%20report_042008.pdf, accessed on 24 April 2009).

4. Johnston HB. Relationships of exclusion and cohesion with health: the case of Bangladesh. J Health Popul Nutr 2009;27:426-40.

5. Khan SI, Hussain MI, Parveen S, Bhuiyan MI, Gourab G, Sarker GF et al. Living on the extreme margin: social exclusion of the transgender population (hijra) in Bangladesh. J Health Popul Nutr 2009;27:441-51.

6. Koehlmoos TP, Uddin MJ, Ashraf A, Rashid M. Homeless in Dhaka: violence, sexual harassment, and drugabuse. J Health Popul Nutr 2009;27:452-61.

7. Modie-Moroka TM. Does level of social capital predict perceived health in a community? - a study of adult residents of low-income areas of Francistown, Botswana. J Health Popul Nutr 2009;27:462-76.

8. Naved RT, Rimi NA, Jahan S, Lindmark G. Paramedicconducted mental health counselling for abused women in rural Bangladesh: an evaluation from 
the perspective of participants. J Health Popul Nutr 2009;27:477-91.

9. Rispel LC, de Sousa CADP, Molomo BG. Can social inclusion policies reduce health inequalities in subSaharan Africa?-a rapid policy appraisal. J Health Popul Nutr 2009;27:492-504.

10. Schurmann AT. Review of the Bangladesh Female Secondary School Stipend Project using a social exclusion framework. J Health Popul Nutr 2009;27:50517.

11. Schurmann AT, Johnston HB. The group-lending model and social closure: microcredit, exclusion, and health in Bangladesh. J Health Popul Nutr 2009;27:51827.

12. Ahmed SM. Capability development among the ultra-poor in Bangladesh: a case study. J Health Popul Nutr 2009;27:528-35.

13. Schurmann AT, Mahmud S. Civil society, health, and social exclusion in Bangladesh. J Health Popul Nutr 2009;27:536-44.
14. Werner W. Micro-insurance in Bangladesh: risk protection for the poor? J Health Popul Nutr 2009;27:56373.

15. Werner W. Corporate social responsibility initiatives addressing social exclusion in Bangladesh. $J$ Health Popul Nutr 2009;27:545-62.

16. Rashid SF. Strategies to reduce exclusion among populations living in urban slum settlements in Bangladesh. J Health Popul Nutr 2009;27:574-86.

17. Khosla N. HIV/AIDS interventions in Bangladesh: what can application of a social exclusion framework tell us? J Health Popul Nutr 2009;27:587-97.

\section{Heidi Bart Johnston}

Public Health Sciences Division

ICDDR,B

GPO Box 128

Dhaka 1000

Bangladesh 